\title{
INFLUENCE OF INFORMATION, MOTIVATION, AND BEHAVIOR OF “TRISNA" TO DRUG COMPLIANCE. NUTRITIONAL STATUS, AND FAMILY SUPPORT IN PATIENTS WITH TUBERCULOSIS
}

\author{
Rita Benya Adriani ${ }^{1}$, Jenita DT Donsu' ${ }^{2}$, Dwi Sulistyowati ${ }^{1}$ \\ ${ }^{1}$ Medical Polytechnic Surakarta, Jl. Letjen Sutoyo, Mojosongo, Kec. Jebres, Surakarta, West Java, Indonesia. \\ ${ }^{2}$ Health Polytechnic Yogyakarta, Jl. Tatabumi No.3, Banyuraden, Gamping, Sleman, Yogyakarta. \\ * Corresponding author: Rita Benya Adriani \\ Email: benyaadriani@gmail.com
}

\begin{abstract}
Indonesia is one of the five countries with the highest number of patients with tuberculosis (TB) worldwide, owing to patients being undetected and untreated. This study aims to analyze the effect of the Information, Motivation, and Behavior (IMB) Skill with "Trisna" approach on the management of drug compliance, nutritional status, and family support for patients with TB. This research is a quasi-experiment with pretest-posttest and control group design. Information about tuberculosis, medication adherence, nutritional status, family support and motivation are provided through training. At the end of training, each patient is given an alarm clock that can be used as a reminder to take medication. One form of family support is done by teaching the song "satu-satu" to remind patients to take medicine so as to minimize forgetting to take medicine. "TRISNA" is an attitude that accompanies TB cadres in providing health services to TB patioents. The socialization of the attitude of "TRISNA" was given by researchers to TB cadres before carrying out IMB training for TB patients. Compliance after intervention in the intervention group (mean, 10.80; SD, 0.98 ) was higher than in the control group (mean, 10.46; SD, 1.12) and effect size (ES) value of 4.16. Body mass index (BMI) in the intervention group (mean, 23.40; SD, 1.08) was higher than in the control group (mean, 21.43; SD, 0.75) and ES value of 1.95. Family support in the intervention group (mean, 106.28; SD, 22.00) was higher than in the control group (mean, 94.00; SD, 8.40) and ES value of 0.69. In managing patients with TB, the provision of IMB Intervention Skill with "Trisna" approach could improve medication compliance, nutritional status, and family support.
\end{abstract}

Keywords: IMB; medication; nutritional status; Trisna; tuberculosis

\section{INTRODUCTION}

Tuberculosis (TB) is an infectious disease that spreads through the air and can kill about two million people per year ${ }^{1}$. Bacteria are transmitted through tiny droplets in the air of positive smear TB sufferers when coughing ${ }^{2}$. TB is caused by the Mycobacterium group, namely, Mycobacterium, including M. tuberculosis, M. africnum, M. bovis, and $M$. leprae, which are acid-resistant bacteria. These bacteria not only attack the lungs (pulmonary TB) but also other organs, such as the lymph, brain membranes, skin, bones, joints, intestines, and kidneys (extrapulmonary disease $)^{3}$.

The World Health Organization (WHO) data 2015, stated that Asia contributed $56 \%$ of TB sufferers in the world in 2013, followed by Africa (29\%), Europe (4\%), and America (3\%). The five countries worldwide with the highest numbers of TB sufferers are India, China, South Africa, Indonesia, and Nigeria. In 2014, TB caused the death of 1.5 million people, consisting of 890,000 men, 480,000 women, and 140,000 children. In addition, the development of TB in the last 10 years (2005-2015) has increased from 8.4 million per year to 10 million in 2005 and has slightly decreased to 9.6 million per year in 2015 . Meanwhile, the WHO study showed that the TB incidence was about 319/100,0004,5.

The rapid transmission of TB infection is affected by the nutritional status of a person. TB affects food intake and causes weight loss $^{6}$. A malnourished person has low immunity; therefore, malnourished individuals are easily infected with TB. Compared to patients with TB who have normal nutritional status, TB sufferers who have malnutrition status will have a slow healing period, thus increasing their mortality risk ${ }^{7}$. The nutritional status and body weight of patients with TB who are AFB-positive are affected, and the effect is inversely proportional to the bacteria present in the body ${ }^{8}$. Good nutritional condition will prevent the recurrence of TB' .

In social marketing, Information, Motivation, and Behavior (IMB) Skill with the "Trisna" approach ${ }^{10}$, a process that uses marketing principles and techniques, is used to influence and change the behavior of people ${ }^{11}$. IMB helps in controlling patients with TB who are resistant to drugs ${ }^{12}$. IMB, which is based on appropriate technology, is proven to support patients with TB in medication compliance $^{13}$. 
The "Trisna" approach is rarely used in research by medical personnel. It needs to be implemented to determine its success level. "Trisna" is the values of Javanese teachings, and the meanings of each letter are as follows: T means friendship, honesty, fairness, and earnestness in running a business with good planning, implementation, and responsibility; $\mathrm{R}$ means sincerity in giving good material, mind, energy, or service to others in need; $\mathrm{S}$ means patience and not easily giving up in running a business, for example, in care or healing, looking calm, not rushing or being hasty, being humble or not arrogant, applying compassion, and not wanting to conflict; and $\mathrm{N}$ means narima or accepting business results happily, whether good or not, according to the expectations, as well as always trying to be grateful in dealing with problems. In the Javanese cultures, friendship, sincerity, patience, and narima, abbreviated as "Trisna," must be cultivated in humans, to serve with love, service, sacrifice, and effort. These serve in Indonesia mean "Trisna", which used as an approach in this study. Research on the effectiveness of "Trisna" approach is important as the TB transmission rate in Indonesia is increasing. This study aims to analyze the effect of IMB with the "Trisna" approach on the management of drug compliance, nutritional status, and family support for TB sufferers."

\section{MATERIALS AND METHODS}

\section{Research Design}

Quasi-experiment was used in this research. This study was conducted at Mojosongo Village, Jebres, Surakarta City, and Panggungharjo Village, Sewon, Bantul, Yogyakarta City, Indonesia.

\section{Ethical Clearance}

Health Research Ethics Committee of Health Polytechnic of the Ministry of Health, Surakarta, with No. LB. 02.02/1. 3/9152/2020.

\section{Sample and Population}

The target populations were 21 respondents in the intervention groups in Mojosongo Village and 15 respondents in the control groups in Panggungharjo Village. This study used a total sampling technique; 36 individuals were included in the sample. The data were obtained for nine months (from January to September 2020). This study included those patients with TB who wanted to become respondents and excluded those who refused.

\section{Research variable}

The dependent variables in this study were medication compliance, nutritional status, and family support. The independent variable in this research was the IMB with "Trisna" approach.

\section{Variable Operational Definition}

1. Compliance with taking Medication, means an individual who took medication obediently under the advice of the healthcare professional.

2. Nutritional status means anthropometric assessments in which body mass index (BMI) was used.

3. Family support means Patients with TB statement who got support from the family members who dealt with TB disease.

\section{Data Analysis}

Univariate analysis was performed to describe the sample characteristics. Bivariate analysis was measured by t-test. The quasi-experimental analysis was conducted using the application, Stata statistical software version 13 .

Research Ethics

All the procedures have been performed as per the ethical guidelines outlined by the Declaration of Helsinki with the ethical No. LB. 02.02/1. $3 / 9152 / 2020$. Each patient was informed of the potential risks and benefits involved in the procedure using the patient's language.

\section{RESULT}

\section{Univariate Analysis}

Table 1 depicts the continuous data of patients with TB. Based on the continuous data, the average age of patients was 46 years and the average time span of suffering from TB was 5 months. In addition, the average compliance in taking TB medication before and after intervention was also measured, which was 9.91 and 13.00 , respectively. BMI before and after intervention were 21.33 and 22.62, respectively. Family support before and after intervention were 91,66 and 101.16, respectively.

Table 2 depicts the results of the data in a categorical form. The ages of patients with TB were as follows: 18 people were $<46$ years old $(50.00 \%)$, whereas 18 people were $\geq 46$ years $(50.00 \%)$. Education was divided into four categories: elementary school (SD), 11 people (30.56\%); junior high school (SMP), 5 people (13.89\%); senior high school (SMA), 17 people (47.22\%); and higher education, 3 people (8.33\%). The jobs of patients with TB were as follows: housewives $(n=12 ; 33.33 \%)$, private jobs $(n=22$; $61.11 \%)$, and State Civil Apparatus ( $n=1 ; 2.78 \%)$; one participant was a student $(2.78 \%)$. There were 20 male participants $(55.56 \%)$ and 16 female participants (44.44\%). 
Table 1. Continuous data of the characteristics of patients with TB

\begin{tabular}{llllll}
\hline Variable & $\mathrm{n}$ & Mean & $\mathrm{SD}$ & Min & Max \\
\hline Age & 36 & 46.02 & 17.90 & 16 & 83 \\
Time span of suffering & 36 & 4.61 & 2.03 & 1 & 9 \\
$\begin{array}{l}\text { Compliance for taking medication before intervention } \\
\text { Compliance for taking medication after intervention }\end{array}$ & 36 & 9.91 & 0.99 & 8 & 12 \\
BMl before intervention & & & & & \\
BMl after intervention & 36 & 13.00 & 2.40 & 8 & 16 \\
Family support before intervention & & & & & \\
Family support after intervention & 36 & 21.33 & 2.03 & 17.56 & 25.96 \\
& 36 & 22.62 & 1.33 & 20.13 & 25.02 \\
& 36 & 91.66 & 8.35 & 77 & 110 \\
& 36 & 101.16 & 18.47 & 11 & 114 \\
\hline
\end{tabular}

Note: BMI: Body Mass Index

Table 2. Characteristics of data categorical samples of patients with TB

\begin{tabular}{lll}
\hline Variable & $\mathrm{n}$ & Percentage (\%) \\
\hline Age: & 18 & \\
<46 years & 18 & 50.00 \\
$\geq 46$ years & 11 & 50.00 \\
Education: & 5 & 30.56 \\
Elementary school & 17 & 13.89 \\
Junior high school & 3 & 47.22 \\
Senior high school & & 8.33 \\
Higher education & 12 & 33.33 \\
Job: & 22 & 61.11 \\
Housewife & 1 & 2.78 \\
Private job & 1 & 2.78 \\
State Civil Apparatus & & \\
Student & 20 & 55.56 \\
Gender: & 16 & 44.44 \\
Male & & \\
Female & & \\
\hline
\end{tabular}

\section{Bivariate Analysis}

Table 3 depicts a bivariate analysis with the following results: TB drug compliance before intervention in the intervention group $(n=21$; mean, 8.95; SD, 2.34) and control group $(n=15$; mean, 9.26; SD, 1.08), with a significance value of $p=0.358$ and effect size (ES) value of -0.31 , and compliance in taking TB medication after intervention in the intervention group $(n=21$; mean, 10.80; SD, 0.98) and control group $(n=15$; mean, 10.46; SD, 01.22), with a significance value of $p<0.001$ and ES of 4.16.

In addition, Table 3 also shows the following: BMI of patients with TB before intervention in the intervention group $(n=21$; mean, 21.92; SD, 0.80$)$ and control group ( $\mathrm{n}=15$; mean, 20.50; SD, 1.22), with a significance value of $p<0.001$ and ES value of 0.73 , and BMI of patients with TB after the intervention in the intervention group $(n=21$, mean, 23.40; SD, 1.08) and control group $(n=15$; mean, 21.43; SD, 0.75), with a significance value of $p<0.001$ and ES value of 1.95 .

In addition, the following results were also shown in Table 3: family support for TB sufferers before the intervention in the intervention group $(n=21$; mean, 91.80; SD, 7.97) and control group $(n=15$; mean, 91.46; SD, 9.14), with a significance value of $p<0.097$ and ES value of 0.05 , and family support for TB sufferers after intervention in the intervention group $(n=21$; mean, 106.28; SD, 22.00) and control group $(n=15$; mean, 94.00; SD, 8.40 ), with a significant value of $p=0.004$ and $E S$ value of 0.69 .

\section{DISCUSSIONS}

Compliance In Taking TB Medication 
The intervention given was statistically significant to improve the compliance of patients with TB in taking medications regularly. In this case, compliance in taking medication in patients with TB was developed with the help of the advice of health workers. Strong self-motivation was a major factor in the compliance of patients with TB in their drug therapy. Motivation factors greatly affect the maintenance of the health of patients with TB, thus controlling their TB. Belief in oneself, a spiritual dimension, can also affect patient compliance. Patients who had beliefs would have a steadfast spirit; they were not easily discouraged and accepted their situation ${ }^{14}$.

Table 3. Bivariate analysis of patients with TB

\begin{tabular}{|c|c|c|c|c|c|}
\hline Variable Group & $\mathrm{n}$ & Mean & SD & $p$ & Size Effect \\
\hline \multicolumn{6}{|c|}{$\begin{array}{l}\text { Compliance in taking TB medication before } \\
\text { intervention: }\end{array}$} \\
\hline Intervention & 21 & 8.95 & 0.80 & 0.358 & -0.31 \\
\hline Control & 15 & 9.26 & 1.22 & & \\
\hline \multicolumn{6}{|c|}{$\begin{array}{l}\text { Compliance in taking TB medication after } \\
\text { intervention: }\end{array}$} \\
\hline Intervention & 21 & 10.80 & 0.98 & $<0.001$ & 4.16 \\
\hline Control & 15 & 10.46 & 1.12 & & \\
\hline \multicolumn{6}{|l|}{ BMI before intervention: } \\
\hline intervention & 21 & 21.92 & 2.34 & $<0.001$ & 0.73 \\
\hline Control & 15 & 20.50 & 1.08 & & \\
\hline \multicolumn{6}{|l|}{ BMI after intervention: } \\
\hline Control & 15 & 21.43 & 0.75 & & \\
\hline \multicolumn{6}{|l|}{$\begin{array}{l}\text { Family support before intervention: } \\
\text { Intervention }\end{array}$} \\
\hline Control & 21 & 91.80 & 7.97 & 0.097 & 0.05 \\
\hline $\begin{array}{l}\text { Family support after intervention: } \\
\text { intervention }\end{array}$ & 15 & 91.46 & 9.14 & & \\
\hline Control & $\begin{array}{l}21 \\
15\end{array}$ & $\begin{array}{l}106.28 \\
94.00\end{array}$ & $\begin{array}{l}22.00 \\
8.40\end{array}$ & 0.004 & 0.69 \\
\hline
\end{tabular}

Note: BMI: Body Mass Index

Willingness and motivation to recover also influenced patient compliance. TB sufferers might already understand their disease, and the understanding of their disease will make them take their medication according to the type, dose, method of taking, drinking time, and the number of days of taking the appropriate medicine recommended by the doctor. TB sufferer compliance is a vital factor. At a predetermined time, the TB bacteria might have immunity to anti-TB drugs (OAT); this is widely known as multidrug resistance. Generally, patients take medication for 6 months to ensure their recovery, but in some circumstances, it may take longer ${ }^{15}$.

The high level of medication compliance among respondents can be affected by several factors; these include the following: (1) free medicines and health services, (2) once-daily dosing regimens during the intensive phase, (3) mild and corrective side-effects such as nausea, (4) clear written instructions for taking medication, and (5) a health service center that is easily accessible to the public ${ }^{16}$.

Differences in illness behavioral patterns are also influenced by gender. Women heal at a faster pace than men ${ }^{17}$. Women seemed to be more diligent in taking medication. Researchers argue that the differences between men and women also affect a person's compliance. Men tend to prioritize rationality without paying attention to 
emotion (feelings), whereas women are opposite and are more diligent in taking medication. The older you are, the more mature and stronger in thinking and working you will be. In terms of public trust, someone who is more mature will be more trusted than someone who is not mature enough ${ }^{18}$.

Some patients with TB do not comply with taking the drug completely, as pulmonary TB medicine must be consumed for a long period. A long treatment period can cause psychological pressure on TB sufferers. According to the results of interviews and questionnaires filled out by patients, the low level of patient compliance is generally because patients feel that their disease reduced or symptoms disappeared 1-2 months or more after undergoing therapy. Sufferers do not continue the treatment seriously again. Another reason is the side-effects of TB drugs, which include reduced appetite of the patient ${ }^{19}$. It is also possible that sufferers become bored with the long-term treatment and that they lack understanding regarding the effects of the drug. There is a disease history requiring the patient to take various drugs differently every day. The number of drugs and rules in taking different drugs can make patients feel confused and bored, potentially causing treatment noncompliance ${ }^{20}$.

\section{The Effect of BMI in Improving the Nutritional Status of Patients With TB}

Treatment is also related to the nutritional status of a patient. The better the immune system of the body, the lower the use of nutrients in fighting infection; therefore, nutrients can be optimally used for the growth process. For example, in children, their nutritional status can increase. Apart from treatment, the intake of sufficient energy and protein can support the healing process and improve the nutritional status of children with TB infection.

TB treatment is divided into two phases: the initial and advanced phases. The initial phase is a treatment for 2 months, whereas the advanced phase lasts for 6-12 months. The drugs given in the early phase are Isoniazid, Rifampin, and Pyrazinamide, whereas Isoniazid and Rifampin are given in the advanced phase. This drug kills the TB bacteria. The side-effects of this drug include nausea, vomiting, anorexia, and headache. This effect can result in decreased appetite ${ }^{21}$.

TB can reduce energy intake by changing the metabolism through decreasing appetite as part of the inflammatory and immune response. A study in Uganda found that there was a decrease in the number of nutrients, consisting of macronutrients and micronutrients, such as carbohydrates, energy, protein, total fat, calcium, vitamin $\mathrm{A}$, and folate, in patients with $\mathrm{TB}^{22}$. Poor nutrition is a vital risk factor for $T B$, as cell-mediated immunity is the main key for fighting $\mathrm{TB}^{23}$.

Family cultural factors can affect nutritional intake. For example, unequal food distribution in the family can affect the nutritional status of women. This can happen due to several factors, such as the habits of women, in which they are trained to reduce food consumption to prioritize certain family members to eat first and provide the best food for men ${ }^{24}$. This is also the same in the case of men, in which they tend to consume more varied and high-quality food from restaurants.

Increasing energy requirements and worsening the condition of patients and food supplies affected the recovery of TB patients. Body wasting, a decrease in $\mathrm{BMI}$, is a characteristic of patients with TB. Wasting causes the body to be nonfunctional, and if left untreated, it will cause death in patients with TB. Patients with TB can experience wasting for months, even after the patient has started OAT therapy. Inadequate nutrition increases the risk of TB infection changing into active TB and also increases the risk of death ${ }^{25}$.

The risk of death happened when nutritional status influence the TB patients. There is a relationship between malnutrition status and the risk of contracting TB. The poor nutritional status will increase the risk of TB. On the other hand, TB affects the nutritional status of the patient. Many patients with active pulmonary TB experience dramatic weight loss, and some show vitamin and mineral deficiencies. Several factors, such as decreased appetite and food intake, increased metabolic loss, and changes associated with inflammatory and immune responses, can cause the above case ${ }^{23}$.

\section{Family Support to Patients With TB}

Family and community support plays a critical role in improving patient treatment. Interviews with several respondents indicated that some of the roles of PMO remain low; they only remind them to take drugs and control them regularly. This is probably due to the lack of knowledge of PMO about the importance of PMO for patients with pulmonary TB and TB counseling ${ }^{26}$.

It is hoped that family support can inspire patients to try to recover. One of the duties of the family is to take care of family members who are sick. The family should be able to carry out these duties to achieve an optimal degree of health.

In real life, the optimal degree of health is achieved by the efforts of each family member, it should be achieved through the cooperation of all members. Not all families can understand the 
patient's situation and needs. Family through a good approach can psychologically ease the burden felt by the patient. According Smet (1994) people who feel they receive the comfort, attention, and help they need from the social support can follow medical advice more easily than patients who do not. Therefore, the family is responsible for providing support both physically and psychologically ${ }^{27}$.

Emotional support means a sense of empathy and sympathy the patients receive from family members, making the patient feel that they are not alone in bearing the burden of the pain he is suffering from. Families provide a sense of comfort and care for TB sufferers during the treatment period. With this, patients will improve their health and recover faster ${ }^{28}$.

Family can be a very influential factor in determining individual health beliefs and values and the treatment program they can receive. Family support is a vital factor in medical compliance programs ${ }^{29}$.

Family support and TB treatment achievement have been studied by many researchers, including research conducted by Rachmawati, Laksmiati, and Soenarsongko ${ }^{30}$. Family support has a vital role in the compliance of patients with pulmonary TB. The family is also responsible for acting as the supervisor of taking drugs (PMO); the family is expected to play a key role in monitoring and reminding patients continuously so that patients will take their medicines regularly and on time according to the dosage set by the health officer $^{30}$.

The relationship between family support and patient compliance to take the medicine means that the families as a supervisor. If the family members did not support the patient, it risks 3.013 times the patient not comply with sputum re-examination in the final phase of treatment compared to patients who have good family support ${ }^{31}$.

Family support is one of the factors that influence pulmonary TB treatment compliance, where the nuclear family and extended family function as a support system for family members. The basic function of the family is the healthcare function. The healthcare function is the family's ability to care for family members who have health problems $^{32}$.

Families need to provide positive support as this will lead to cooperation in monitoring treatment between officers and family members who are sick ${ }^{33}$.

\section{RESEARCH LIMITATION}

The research was carried out in between the pandemic period. Grateful that before the social restriction was implemented, the training had been carried out. Hence, the monitoring of the implementation of "TRISNA" IMB was carried out online. The researcher hopes that the" TRISNA" IMB service model can be developed and can also the given to other palliative patients.

\section{CONCLUSIONS}

This study concludes that the provision of IMB Intervention Skill with "Trisna" approach can improve treatment compliance, nutritional status, and family support in the treatment of patients with TB. In the scientific field, IMB "TRISNA" contributes as a model for the development of public health services. Besides that, can be applied by public health service institutions in managing TB patients. It can also be given in managing other palliative patients.

\section{REFERENCES}

1.Keshavjee S, Farmer PE. Tuberculosis, drug resistance, and the history of modern medicine. N Engl J Med 2012; 367: 931-936.

2. Mahan LK, Merianne. Krause's Food and Nutrition Therapy. 12th ed. Philadelphia: Saunders Elsevier 2008.

3. Health Ministry of Indonesia. Pedoman Nasional Pengendalian Tuberkulosis. Jakarta: Kemenkes RI 2014. [in Indonesian].

4. World Health Organization (WHO). Global Tuberculosis Report. Europe: World Health Organization publication, 2015. (accessed 15 June 2019).

https://apps.who.int/iris/handle/10 $\underline{665 / 191102}$

5. World Health Organization (WHO). Global Tuberculosis Report. Europe: World Health Organization publication 2018, https://www.who.int/TBC/publicati ons/global_report/en/; 2018 [accessed 13 June 2019].

6.Gupta KB, Gupta R, Atreja A, Vema $M$, Vishvkarma S. Tuberculosis and nutrition. Lung India 2009; 26:9-16.

7.Dargie B, Tesfaye G, Worku A. Prevalence of undernutrition among adult tuberculosis patients in Ethiopia: A systematic review and 
meta-analysis. Wondmieneh A, Gedefaw G, Getie A, Demis A. Prevalence of undernutrition among adult tuberculosis patients in Ethiopia: A systematic review and meta-analysis. J Clin Tuberc Other Mycobact Dis 2020; 22:100211.

8.Praygod G, Range N, Faurholt-Jepsen D, Jeremiah $K$, Faurholt-Jepsen M, Aabye MG, et al. The effect of energy-protein supplementation on weight, body composition and handgrip strength among pulmonary tuberculosis HIV-co-infected patients: randomised controlled trial in Mwanza, Tanzania. Br J Nutr 2011; 107:263-271

9.Sianturi R. Analisis Faktor Yang Berhubungan Dengan Kekambuhan TBC Paru, 2014. [accessed 13 June 2019].

http: / / lib.unnes.ac.id/17921/1/6411 409109.pdf.

10.Fisher WA, Fisher, JD, Harman J. The Information-Motivation, Behavioral Skills Model: A General Socia Psychological Approach to Understanding and Promoting Health Behavior. In: Suls J, Wallston KA, editors. Social Psychological Foundation of Health and Illness. Victoria, Australia: Australia Blackwell Publishing, Ltd 2003: 82-106.

11. Kotler P, Lee NR. Social Marketing: Influencing Behaviors for Good. 2011. New York: Sage Publications 2011.

12.Kanjee Z, Amico KR, Li F, Mbolekwa K, Moll AP, Friendland GH. Tuberculosis infection control in a high drug-resistance setting in Rural South Africa: Information, motivation, and behavioral skills. $J$ Infect Public Health 2012;5:67-81.

13.Irribaren SJ, Beck SL, Pearce PF, Chirico C, Etchevarria M, Rubinstein F. Health intervention development to support patients with active tuberculosis. J Mob Technol med 2014;3:16-27.

14.Morisky DE, Ang A, Krousel-Wood M, Ward HJ. Predictive validity of a medication adherence measure in an outpatient setting. J Clin Hypertens (Greenwich) 2008; 10:348-354.
15. Health Ministry of Indonesia. Pedoman Penanggulangan Tuberkulosis. Jakarta: Depkes RI 2006. [in Indonesian]

16.Bello SI, Itiola OA. Drug Compliance amongst tuberculosis patients in the University of Ilorin Teaching Hospital, Ilorin, Nigeria. Afr J Pharm Pharmacol 2010; 4:109-114.

17. Notoatmodjo S. Pendidikan dan Perilaku Kesehatan. Jakarta: Rineka Cipta; 2010. [in Indonesian]

18. Hurlock. Psikologi Perkembangan. 5th ed. Jakarta: Erlangga; 1998.

19.Snewe FP. Faktor-faktor yang mempengaruhi kepatuhan berobat penderita tuberkulosis paru. Depok. Bul Penel Kesehatan 2002; 30:32-38.

20. Hayati A. Evaluasi Kepatuhan Berobat Penderita Tuberkulosis Paru Tahun 2010 -2011 di Puskesmas Kecamatan Pancoran Mas Depok. Jakarta: Fakultas IImu Matematika dan IPA Departemen Farmasi 2011

21.Pusponegoro HD, Sri RSH, Dody F, Bambang TA, Antonius HP, Sholeh MK, Rusmil K. Standar pelayanan medis kesehatan anak. 1st ed. 2005. Jakarta: IDAI (Ikatan Dokter Anak Indonesia) 2005. [in Indonesian]

22.Ezekiel M, Isabel MP, Daniel JT, Harriet KM, Christopher CW. Low nutrient intake among adult women and patients with severe tuberculosis disease in Uganda: A Cross-Sectional Study. BMC Public Health 2012; 12: 1050-1057.

23.Cegielski P, McMurray DN. The relationship between malnutrition and tuberculosis; evidence from studies in humans and experimental animals. Int J Tuberc Lung Dis 2004; 8: 286-298.

24. Meena M. Impact of nutrition education on pulmonary tuberculosis patients. Global Journal for Research Analysis 2016;5: 317-320.

25. Yung-Feng $Y$, Pei-Hung C, MuhYong Y, Shu-Yi L, Pei-Chuang, Mei-Jen Y, et al. Association of body mass index with tuberculosis mortality. Medicine 2016;95: e2300. 
26.Tirtana B. Faktor-faktor yang mempengaruhi keberhasilan pengobatan pada pasien tuberkulosis paru dengan resistensi obat tuberkulosis di wilayah Jawa Tengah, 2011. [accessed 13 June 2019] http:/ / eprints.undip.ac.id/32879/1/ Bertin.pdf. [in Indonesian]

27.Smet B. Psikologi Kesehatan. Jakarta: EGC 1994.

28. Kusumoningrum TA, Susanto N, Marlinawati VU, Puspitawati T. Hubungan Dukungan keluarga dan kepatuhan minum obat terhadap kesembuhan penderita tuberkulosis (TB) di Kabupaten Bantul. Jurnal Formil (Forum Ilmiah) KesMas Respati 2020;5: 29-35. [in Indonesian]

29. Niven, N. Psikologi Kesehatan. Jakarta: EGC; 2000. [in Indonesian]

30.Perhimpunan Dokter Paru Indonesia. Pedoman diagnosis \& penatalaksanaan tuberkulosis di Indonesia. Jakarta: PDPI; 2008. [in Indonesian]

31.Rachmawati T, Laksmiati T, Soenarsongko. Hubungan kekeluargaan dan tempat tinggal serumah merupakan karakteristik pengawas minum obat yang berpengaruh terhadap keteraturan minum obat penderita tuberkulosis paru. Bulletin Penelitian Sistem Kesehatan 2008;11: 184-191. [in Indonesian]

32. Asra S, Siti R, Febriana S. Hubungan dukungan keluarga dengan kepatuhan minum obat pada penderita TB Paru. Jom Psik 2017;1-10.

33.Pare LA, Amiruddin R, Leida I. Hubungan antara pekerjaan, pmo, pelayanan kesehatan, dukungan keluargadan diskriminasi dengan perilaku berobat pasien TB Paru, 2012. [accessed 13 June 2019]. www. jurnal.unair.ac.id/index.P2hp/j $2222 \mathrm{mpk} /$ article/download/2342222 2 22225/ 264 [in Indonesian] 